\title{
State-Owned Entities as Key Actors in the Promotion and Implementation of the 2030 Agenda for Sustainable Development: Examples of Good Practices
}

\author{
Mihaela-Maria Barnes (D) \\ Graduate Institute of International and Development Studies, 1202 Geneva, Switzerland; \\ mihaela.barnes@graduateinstitute.ch
}

Received: 12 March 2019; Accepted: 25 March 2019; Published: 9 April 2019

\begin{abstract}
The purpose of this article is to demonstrate that a wide range of entities associated with the State and which engage in business or investment activities on behalf of the State have an important role to play in the promotion and implementation of the sustainable development goals found in the 2030 Agenda. The contribution starts with a background to the 2030 Agenda, followed by an introduction to the features of State-owned entities. Since the 2030 Agenda requires the 'mobilization of all available resources' to achieve its implementation, it is argued that entities that are owned by States could have a significant role to play in this context. Examples of good practices from a number of jurisdictions show how the development and implementation of domestic measures that cover State-owned entities have the potential to contribute to the promotion and implementation of the 2030 Agenda.
\end{abstract}

Keywords: Agenda 2030; sustainable development; State-owned entities; mobilization of resources; human rights; business and human rights; regulation

\section{Introduction}

The 2030 Agenda for Sustainable Development (Agenda 2030), was unanimously adopted by 193 States in the United Nations General Assembly in late September $2015^{1}$ and sets out a three-dimensional plan of action concerning sustainable development, which covers people, the planet, and prosperity, ${ }^{2}$ by outlining 17 Sustainable Development Goals (SDGs) and 169 targets correlating with each SDG. ${ }^{3}$ The key enablers of the SDGs are peace and the fostering of partnerships for sustainable development. ${ }^{4}$ Importantly, Agenda 2030 contains provisions concerning the means of implementation, follow-up, and review. ${ }^{5}$ The SDGs and corresponding targets came into effect on 1 January 2016 and should guide States' decision-making for the next 15 years.

Broadly, sustainable development encapsulates the idea that development must be pursued in a manner that 'meets the needs of the present without compromising the ability of future generations to meet their own needs'. ${ }^{6}$ Sustainable development seeks to ensure the preservation

(UN General Assembly 2015a).

2 The 17 SDGs are as follows: Goal 1: No Poverty; Goal 2: Zero Hunger; Goal 3: Good Health and Wellbeing; Goal 4: Quality Education; Goal 5: Gender Equality; Goal 6: Clean Water and Sanitation; Goal 7: Renewable Energy; Goal 8: Good Jobs and Economic Growth; Goal 9: Innovation and Infrastructure; Goal 10: Reduced Inequalities; Goal 11: Sustainable Cities and Communities; Goal 12: Responsible Consumption; Goal 13: Climate Action; Goal 14: Life Below Water; Goal 15: Life on Land; Goal 16: Peace and Justice; Goal 17: Partnerships for the Goals.

(UN General Assembly 2015a).

Ibid.

(UN General Assembly 2015a). See in this context, the Preamble, SDG 17 and paragraphs 17, 39-46, 60-71 and 72-91.

(World Commission on Environment and Development 1987). 
of intragenerational and intergenerational equity, encourages sustainable use of resources and the integration of environmental protection and development processes. ${ }^{7}$ The Rio Declaration on Environment and Development brought sustainable development into the legal domain, which, although not binding, is drafted in imperative language. ${ }^{8}$ Sustainable development is a very broad and evolutive concept that encapsulates not only the environmental but also the social and economic spheres. The concept of sustainable development is variable 'ratione personae' and 'ratione materiae'. ${ }^{9}$ Variability ratione personae is evidenced by the fact that sustainable development commitments expected from developed States may be more onerous than those expected from less developed States. Variability ratione materiae is evidenced through the application of various standards to each situation on a case-by-case basis, which means that each project or endeavour would have to be assessed on its own merits in order to determine which type of standards and requirements are applicable in that particular case. From an international law perspective, there has been a wide debate in academic circles as to whether the concept of sustainable development could or should be considered as being part of international law or not. ${ }^{10}$ While sustainable development principles are part of the international law treaty architecture, since over 300 conventions contain such provisions, it is unsettled whether this concept is part of customary international law. ${ }^{11}$ Opponents have argued that in international law there is no general obligation that States 'must' develop sustainably. ${ }^{12}$ Several international dispute settlement bodies, including the International Court of Justice (ICJ), have also considered the importance of sustainable development, but none have declared it as part of customary international law yet. ${ }^{13}$ Some commentators have argued that this is not surprising, since the role of the ICJ is 'not that of a ground-breaking body but rather that of a stock-taking institution' whose main purpose is to be a 'guardian' of general international law. ${ }^{14}$ Other commentators have suggested that sustainable development is an 'interstitial norm,' which means that this concept gains its legal relevance from the 'pull' that it exerts on the judicial reasoning process. ${ }^{15}$

Leaving questions of normative status aside, while in the Agenda 2030, States are the main actors through which the SDGs will be achieved, the aim of creating a 'Global Partnership for Sustainable Development' calls for the involvement in this process of other actors such as private businesses, civil society, and international organizations. As such, this article argues that, along with the private sector, State-owned corporate entities could be considered as key actors in the promotion and implementation of the SDGs. The contribution is organized as follows: Section 2 serves as a background to Agenda 2030; Section 3 introduces the specificities of State-owned entities (SOEs); Section 4 examines how Agenda 2030 is supposed to be implemented through a 'mobilization of all available resources' and proposes that SOEs could be considered among the 'resources' that could be used by States to achieve the SDGs; and Section 5 contains examples of good practices and demonstrates how the development and implementation of domestic measures that cover SOEs could have the potential to contribute to the promotion of the SDGs.

\section{The Three-Dimensional Nature of Agenda 2030}

The three-dimensional plan of action set out in Agenda 2030 builds upon the Millennium Development Goals and aims to 'complete what they did not achieve'. ${ }^{16}$ The dimensions covering

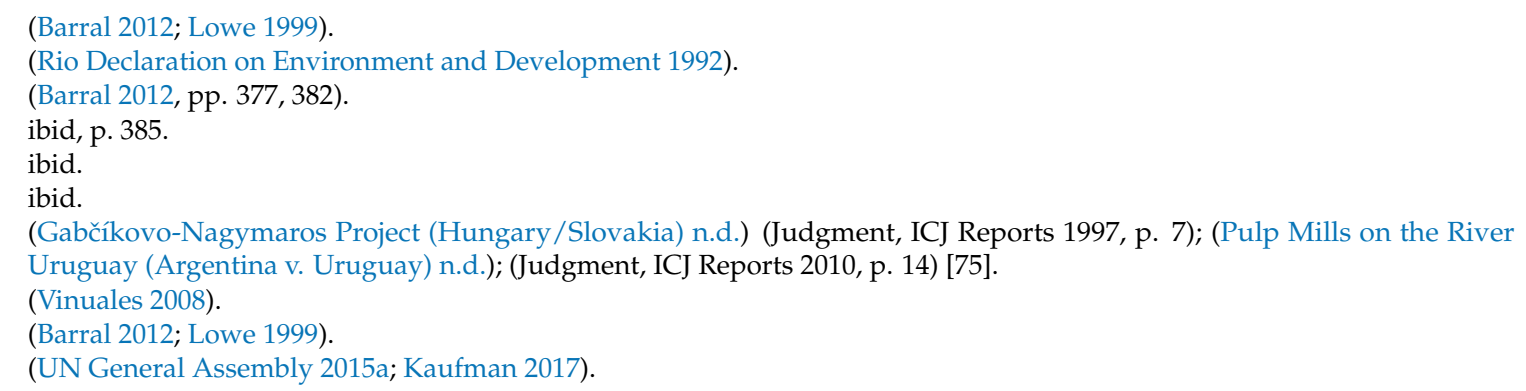


people and prosperity have the main goals of ending poverty, hunger, and ensuring prosperity, so that 'all human beings can fulfill their potential in dignity and equality'. ${ }^{17}$ The dimension concerning the planet aims to 'protect the planet from degradation' through sustainable consumption and production, the management of natural resources, and by taking 'urgent action on climate change'. ${ }^{18}$ While the three dimensions may appear as self-contained, there are profound interlinkages between them. ${ }^{19}$ For example, the dimension covering the planet or environment has its own self-contained provisions, but it is also connected with the other two dimensions of people and prosperity. Its self-contained nature is evidenced by the separate treatment in the Preamble and in separate SDGs, such as SDG 13 dealing with 'Climate Action,' SDG 14 addressing 'Life Below Water', and SDG 15 which outlines sustainability targets for 'Life on Land'. The linkages between the environment and the other two dimensions is supported by the acknowledgement that people cannot fulfill their potential in 'dignity and equality' unless they live in a 'healthy environment'. ${ }^{20}$ This approach is in line with recent jurisprudence, which states that a healthy environment is fundamental to the realization of all other human rights. ${ }^{21}$ Furthermore, the economic, social, and technological progress needed to ensure prosperity should occur in 'harmony with nature'..$^{22}$ The key enablers of the SDGs are peace and a global partnership between nations. ${ }^{23}$

Agenda 2030 is not binding and does not create legal obligations for States, but it is nevertheless applicable to all States, both developing and developed. Its implementation is envisaged through the creation of a 'Global Partnership for Sustainable Development' by bringing together governments, the private sector, civil society, the United Nations System, and other actors and by 'mobilizing all available resources' ${ }^{24}$ Ultimately, States have the primary responsibility for the implementation of the SDGs at a national level. ${ }^{25}$ Global, regional, and national indicators for measuring and monitoring the SDGs have also been created in order to facilitate implementation. ${ }^{26}$ The 169 targets are defined as 'aspirational and global', with each State having to set its own national targets guided by 'the global level of ambition', while taking into consideration national circumstances. Despite the fact that Agenda 2030 does not create legal obligations for States, it nevertheless makes explicit reference to international human rights treaties, norms, and principles and emphasizes the responsibilities that States have to respect, protect, and fulfill human rights of all people, without discrimination. ${ }^{27}$ In this sense, the Agenda 2030 is 'unequivocally anchored in human rights'. ${ }^{28}$ The interlinkages between the SDGs and human rights have been clarified in recent research, which indicates that over $90 \%$ of the SDGs' targets are embedded in human rights. ${ }^{29}$ For example, out of the 169 targets for the achievement of the SDGs, 156 have 'substantial linkages to human rights and labour standards', which already have institutionalized monitoring bodies. ${ }^{30}$ The Preamble of the Agenda 2030 also pledges that 'no one will be left behind' and thus embodies the fundamental human rights principles of equality and non-discrimination. ${ }^{31}$ The interlinkages between human rights and the SDGs suggest that Agenda

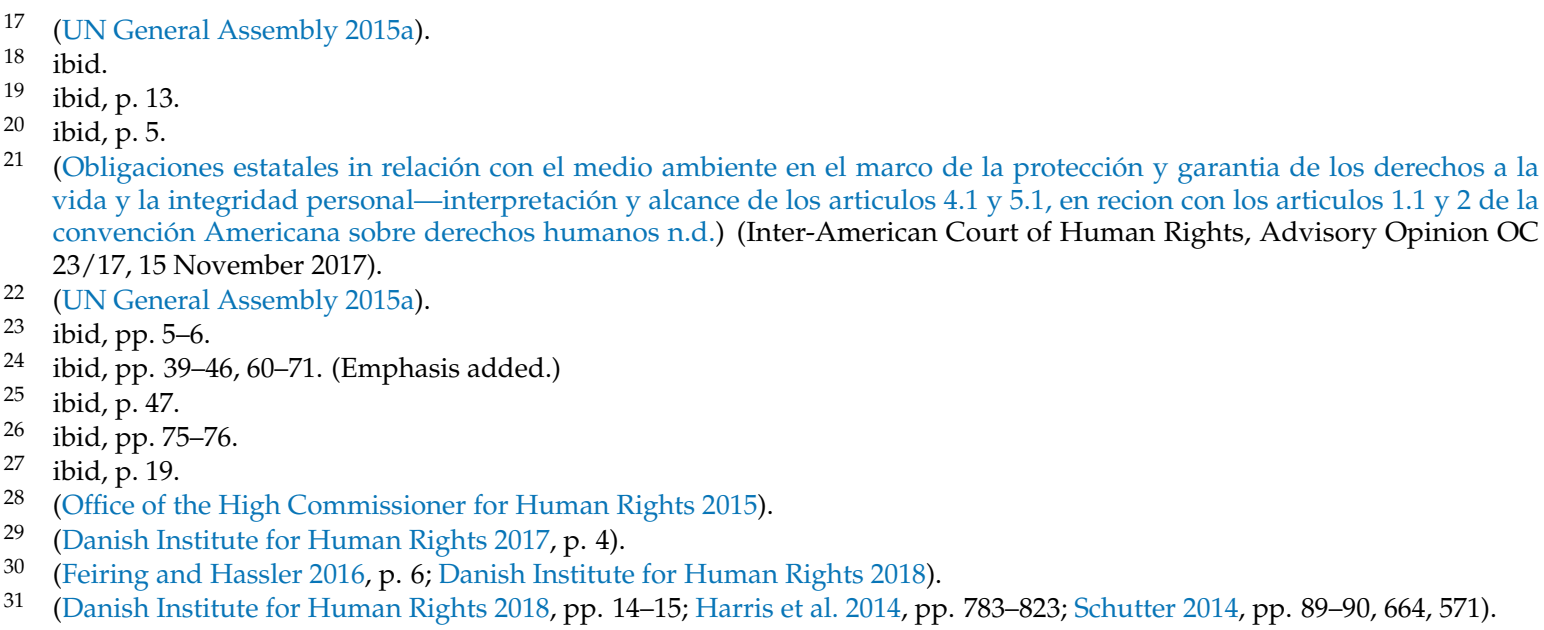


2030 is more than a purely voluntary undertaking ${ }^{32}$ and that the institutional mechanisms currently existent in human rights law, such as the Universal Periodic Review, the Special Procedures, the Treaty Bodies, and National Human Rights Institutions could also be used in the context of the SDGs. ${ }^{33}$ It is also explicitly noted that Agenda 2030 is 'to be implemented in a manner that is consistent with the obligations of States under international law'. ${ }^{34}$ Some commentators have argued that 'human rights offer guidance for the implementation of the Agenda 2030, while the SDGs can contribute substantially to the realisation of human rights ${ }^{\prime}{ }^{35}$ Human rights and sustainable development are considered to be 'interdependent and mutually reinforcing-constituting distinct but converging commitments and obligations that should be realised in a mutually integrated manner ${ }^{\prime}{ }^{36}$ Various other scholars ${ }^{37}$ and UN bodies have also made comments on the interlinkages between human rights and the SDGs. ${ }^{38}$ The United Nations Working Group on Business and Human Rights (UN Working Group) has commented on the need to align the SDGs with the United Nations Guiding Principles on Business and Human Rights (UNGPs) and has issued key recommendations on this topic. ${ }^{39}$ The UN Working Group has clarified that the most important contribution that businesses can make to sustainable development is to 'embed respect for human rights across their value chains,' by ensuring that 'robust' human rights due diligence processes and appropriate accountability mechanisms and remedies are in place. ${ }^{40}$

The implementation of the Agenda 2030 is dependent on the creation of a Global Partnership for Sustainable Development. Contained in SDG 17, the Global Partnership for Sustainable Development does not have a legal basis, given that Agenda 2030 is not binding, but instead it is based 'on a spirit of strengthened global solidarity' and a commitment made by all implementing States. ${ }^{41}$ The fostering of a Global Partnership for Sustainable Development requires the 'mobilization' of a wide range of financial and technological resources, the facilitation of trade and investment, and capacity-building initiatives. Of particular importance is the creation of the Follow-up and Review Mechanism ${ }^{42}$ composed of the High-Level Political Forum on Sustainable Development ${ }^{43}$ the Regional Forum on Sustainable Development, and national bodies designated for this purpose. ${ }^{44}$ The High-Level Political Forum meets annually, under the auspices of the UN Economic and Social Council, and every four years, under the auspices of the UN General Assembly. Its purpose is to receive the Voluntary National Review reports, ${ }^{45}$ which are at the core of the whole Follow-up and Review Mechanism, and to present the progress made by States in the implementation of the SDGs. The High-Level Political Forum also tracks progress, provides political leadership and guidance, and addresses emerging issues. The Regional Forums for Sustainable Development facilitate follow-up and review and focus on the exchange of best practices. Agenda 2030 and the Global Partnership for Sustainable Development should also be read in conjunction with the Addis Ababa Action Agenda on Development Financing, which provides

32 (Danish Institute for Human Rights (n 31), p. 7; Danish Institute for Human Rights and Universal Rights Group (n 29), p. 15). 'SDGs constitute a common roadmap for international development and are underpinned by legal obligations arising from international human rights law. This represents a clear hierarchy of legal obligations'.

(Danish Institute for Human Rights (n 31), pp. 21-45).

(Office of the High Commissioner for Human Rights (n 28) paragraph 18).

(Feiring and Hassler (n 30), p. 6).

(Danish Institute for Human Rights and Universal Rights Group (n 29), p. 3).

7 (Arts 2017; McGoldrick 1996; Giné-Garriga et al. 2017; Tignino 2018).

38 (United Nations Human Rights Commissioner 2016; Committee on the Elimination of Discrimination against Women 2016; Sustainable Development Knowledge Platform 2018). For a comprehensive review of the various resolutions and decisions coming from UN bodies concerning sustainable development see the UN Sustainable Development Platform.

39 (UN Working Group on Business and Human Rights 2017).

40 ibid, pp. 4-6.

41 (UN General Assembly 2015a, (n 1), SDG 17, pp. 39-46).

42 ibid paragraphs $72-91$.

43 (UN General Assembly 2013; UN General Assembly 2016a; UN General Assembly 2016b).

44 (Danish Institute for Human Rights (n 31), p. 17).

45 (Synthesis of Voluntary National Reviews 2017; Handbook for Preparation of Voluntary National Reviews n.d.; Voluntary Common Reporting Guidelines for Voluntary National Reviews at the High-Level Political Forum for Sustainable Development (HLPF) 2018; UNDP 2017). 
a new framework for financing sustainable development, by aligning financial flows and policies with economic, social and environmental priorities. ${ }^{46}$ Overall, the mechanism for implementing the SDGs has been criticized by scholars ${ }^{47}$ and human rights advocates for lacking a 'robust accountability mechanism' for oversight, ${ }^{48}$ so it is likely that challenges in this area will remain. ${ }^{49}$ Certain innovative proposals for social bonds for sustainable development, to harness the private sector through the power of global financial markets have also been made. ${ }^{50}$ However, it should be noted that Agenda 2030 is still at a relatively early stage of implementation and that at the time of writing this article, 143 States have already engaged with the High-Level Political Forum by providing either Voluntary National Review reports or making statements supporting the SDGs, which indicates a high-level of engagement at the State-level. ${ }^{51}$

\section{Agenda 2030 and State-Owned Entities}

While States are some of the main actors through which the SDGs will be achieved, ${ }^{52}$ the goal to create a 'Global Partnership for Sustainable Development' shows that other actors, such as private businesses, civil society, and international organizations, also have a preeminent role to play in this undertaking and that there is a significant potential for policy 'interplay between governments, NGOs and private companies'. ${ }^{53}$ The role of the private business sector in the achievement of the goals enshrined in Agenda 2030 has been summarized as follows:

Private business activity, investment and innovation are major drivers of productivity, inclusive economic growth and job creation. We acknowledge the diversity of the private sector, ranging from micro-enterprises to cooperatives to multinationals. We call upon all businesses to apply their creativity and innovation to solving sustainable development challenges. We will foster a dynamic, and well-functioning business sector, while protecting labour rights and health standards in accordance with relevant international standards and agreements and other ongoing initiatives in this regard, such as the Guiding Principles on Business and Human Rights and the labour standards of the International Labour Organisation, the Convention on the Rights of the Child and key multilateral environmental agreements, for parties to those agreements. ${ }^{54}$

While the involvement of the private sector in the promotion and implementation of the SDG is paramount, it is also necessary to pay equal attention to entities that are connected with the State and that engage in business activities on behalf of States, given their size and importance in the economies of many States. ${ }^{55}$ Yet, there is scant literature on State owned companies and the SDGs, from a legal perspective, despite the fact that this issue is being increasingly analyzed in other fields. ${ }^{56}$ There is

46 (UN General Assembly 2015b).

47 (Voluntary National Reviews: Sustainable Development Knowledge Platform n.d.).

48 (Kaufman (n 16), p. 110).

9 (Xue et al. 2018, p. 157).

(Park 2018).

1 (States: Sustainable Development Knowledge Platform n.d.).

52 (Danish Institute for Human Rights and Universal Rights Group (n 29), p. 4). 'States have a clear self-interest in seeking operational synergies through integrated approaches to planning, implementing, tracking progress, measuring impact, and reporting on their international human rights obligations and sustainable development commitments'.

53 (Lambin and Thorlakson 2018; Hancock et al. 2018; UN General Assembly, 21 October 2015 (n 1); KS et al. 2016). The creation of a Global Partnership for Sustainable development is mentioned throughout Agenda 2030. For this purpose see the Preamble, SDG 17 as well as further discussion in paragraphs 39, 40, 60-71.

54 (UN General Assembly 2015a (n 1) para 67. Further references to the role of the private sector is made in paragraphs [39, 41, 43, 52, 60, 62, 70, 76, 79, 84] and: Goal 5: Gender Equality, target 5.2; Goal 9: Innovation and Infrastructure, target 9.5; Goal 17: Partnership for the Goals, target 17.

55 (Kwiatkowski and Augustynowicz 2015). This paper notes that between 2005 and 2014 the number of Fortune 500 State-owned enterprises increased from $9.8 \%$ in 2005 to $22.8 \%$ in 2014.

56 (Inkpen and Ramaswamy 2018; Hernandez-Perdomo et al. 2017). 
also a growing body of literature on the human rights obligations of States as the owners of SOEs. ${ }^{57}$ The lack of literature could partly be due to the uncertainties that persist about the nature of SOEs. Are SOEs part of the public sector or are they similar to privately owned companies? For example, in OECD Member States, the most common legal form of organization of SOEs is as a limited liability company. 58 The organization of SOEs into statutory companies is also common in other countries. For example, Australia and the United Kingdom, ${ }^{59}$ the Czech Republic, Brazil, Indonesia, ${ }^{60}$ Russia $^{61}$ South Africa, ${ }^{62}$ South Korea and, among many others, France, have specific laws that provide for the organization of SOEs into statutory corporations. ${ }^{63}$ In such cases, it is likely that SOEs will be part of the public sector. Nevertheless, there are also cases when SOEs are governed under general corporate law provisions, just like any other privately owned corporations. Such cases present additional difficulties in terms of classification and some commentators argue that many SOEs are hybrids, which straddle the dividing line between the public and the private domains. ${ }^{64}$ One of the best examples that demonstrates the special nature of SOEs is their treatment in the UNGPs. For example, the UNGPs covers the 'State-business nexus' in Pillar I, under the State duty to protect human rights, while SOEs would also be covered by Pillar II, under the general corporate responsibility to respect human rights. As such, SOEs are believed to 'occupy a dual place within the UNGPs in that they are an instrumentality of the State and thus potentially subject to the State duty to protect' while at the same time being 'commercial ventures subject to the to the corporate responsibility to respect' ${ }^{\prime}{ }^{5}$

The importance of entities that are owned or controlled by the State has steadily increased over the past few decades and they can now found in a 'wide spectrum of industries', such as the natural resources, aerospace, defense, automobile manufacturing, chemicals, transportation, construction, and banking. ${ }^{66}$ For example, in 2014 UNCTAD noted that there were 550 State-owned multinational enterprises operating outside their own borders, which had approximately 15,000 foreign affiliates. ${ }^{67}$ This number increased to 1500 State-owned multinational enterprises in 2017, which had approximately 86,000 foreign affiliates. ${ }^{68}$ Apart from State-owned multinational enterprises, there are many other entities that are owned by States that engage in economic activities and which are equally important. For instance, national oil companies own and control most of the world's energy supply and 73\% of the world's oil reserves, and $61 \%$ of production is State-owned, ${ }^{69}$ while sovereign wealth funds and export credit agencies are crucial for investment flows and played a crucial role during the 2008 economic crisis. ${ }^{70}$ SOEs are also important in the domestic economies of many countries, given that they are often some of the largest employers. For example, Sweden's 2016 Report on State-Owned Enterprises indicated that Sweden has 48 SOEs, which employ 137,000 people. ${ }^{71}$ The situation is similar in China, ${ }^{72}$ Norway, South Africa, France, Brazil, Mexico, India, South Korea, and Russia. ${ }^{73}$ The exact terminology used for entities that engage in economic activities varies from State to State and is ultimately determined by the type of legal structure used in that particular case. However, despite

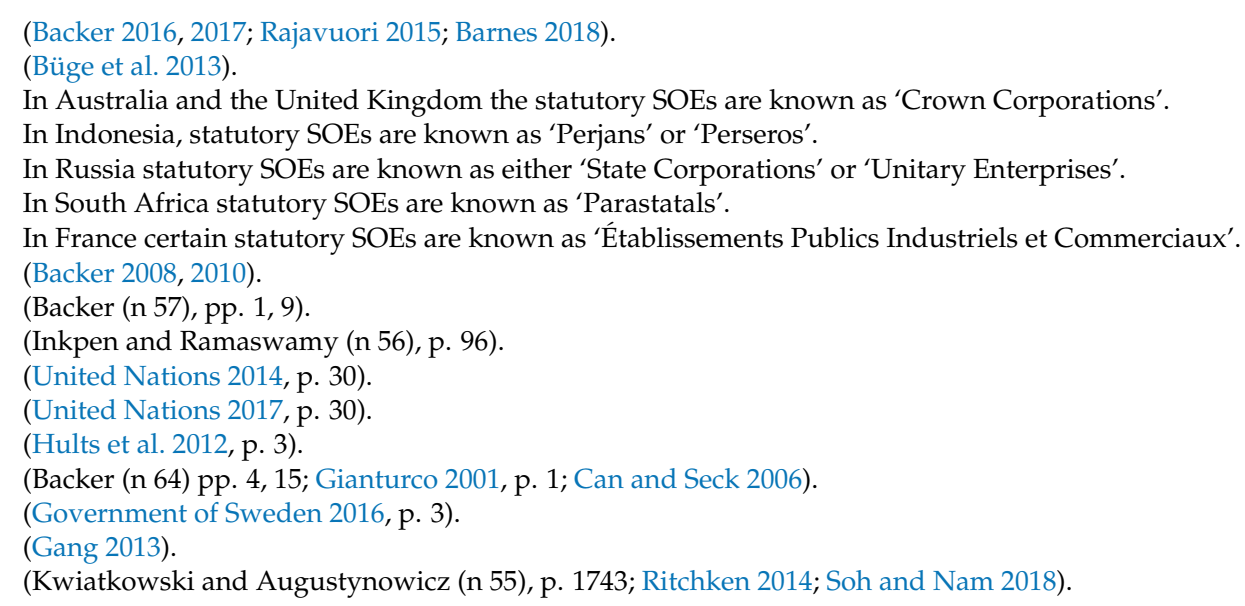


their ultimate legal form, all SOEs share a common characteristic in that they are ultimately owned by a State. As such, for the remainder of this contribution those entities will be referred to as State-owned entities (SOEs). ${ }^{74}$

\section{Mobilizing SOEs as 'Resources' to Achieve the SDGs}

\subsection{Legal Basis for 'Mobilizing' SOEs as 'Resources' at the Disposal of the State}

The implementation of the goals contained in Agenda 2030 is conditional upon the 'mobilization of resources', an issue that is mentioned throughout the text of the document. ${ }^{75}$ Yet, it is not straightforward what the process of 'mobilization' should entail, nor is it clear what those 'resources' might be. Given the interlinkages between Agenda 2030 and human rights, some commentators have suggested that the legal basis for the 'mobilization of resources' can be found in the provisions of the most fundamental human rights instruments. ${ }^{76}$ For example, Article 2(2) of the International Covenant on Civil and Political Rights states the following:

Each State Party to the present Covenant undertakes to take the necessary steps in accordance with its constitutional processes and with the provisions of the present Covenant, to adopt such laws or other measures as may be necessary to give effect to the rights recognised in the present Covenant. ${ }^{77}$

Article 2(1) of the International Covenant on Economic Social and Cultural Rights also has similar provisions, as follows:

Each State Party to the Present Covenant undertakes to take steps, individually and through international assistance and co-operation, especially economic and technical, to the maximum of its available resources with a view to achieving progressively the full realisation of the rights recognised in the present Covenant by all appropriate measures, including the adoption of legislative measures. ${ }^{78}$

The meaning of the concept of 'maximum available resources' is, however, not entirely clear and while there have been attempts to initially limit interpretation to budget expenditures and international assistance, more recently it has been recognized that the approach should be broadened to include resources that go beyond monetary means to include other types of resources, such as 'natural, human, technological, organizational, informational, and administrative'.${ }^{79}$ Consequently, additional sources for mobilizing resources could be in the form of taxation measures, the allocation of natural resource revenues, debt and deficit financing on favourable terms, ensuring that States integrate human rights impact assessments on trade and investment agreements before they are concluded, and the avoidance of 'resource diversion' by taking appropriate measures to tackle corruption, tax evasion, and capital flight. ${ }^{80}$

Given the closeness to the State that owns them, SOEs should be considered as key 'resources' that could be mobilized to fulfill the SDGs and States should adopt the necessary measures to achieve this end. At the international level, a legal basis for this assertion can be found in the numerous comments that have been made by human rights treaty bodies concerning the responsibility of States to regulate all corporate activities. The overall conclusion that has been reached is that States have

74 (Barnes (n 57), p. 47).

75 (UN General Assembly 2015a (n 1). The need to 'mobilize resources' is mentioned in paragraphs 28, 41, 43, and 66 as well as in SDG 1 and SDG 17.

76 (Dommen 2017, pp. 28-29; Balakrishnan et al. 2011).

77 (International Covenant on Civil and Political Rights 1966) (Emphasis added.)

78 (International Covenant on Economic 1966) (Emphasis added.)

79 (Dommen (n 76), pp. 28-29; Balakrishnan and others (n 76).

80 (Dommen (n 76) pp. 50-83). 
'clear obligations to prevent and punish corporate abuse', 'regardless whether the entities in question are private or publicly owned or controlled' and a 'failure to do so will be considered as a violation of treaty obligations' ${ }^{81}$. The human rights treaty bodies have also made express reference to SOEs in several instances. ${ }^{82}$ For example, the Committee on the Elimination of Discrimination Against Women, in its General Recommendation No. 25, requires States to protect women against discrimination by businesses that operate in the public or private sector. The Committee on Economic Social and Cultural Rights, in General Comment No. 15, has also explained the following:

[T] he obligation to protect requires States' parties to refrain from interfering in any way with the enjoyment of the right to water. Third parties includes individual groups, corporations and other entities as well as agents acting under their authority ... [and] includes refraining from engaging in any practice or activity that denies or limits equal access to adequate water; arbitrarily interfering with customary or traditional arrangements for water allocation; unlawfully diminishing or polluting water, for example through waste from State-owned facilities ... ${ }^{83}$

When taking measures to discharge their obligations in regulating corporate entities, States should be guided by soft law instruments that have been developed at the international level, as well as by the practice of other States that have already adopted such measures. The next sections examine several soft law initiatives that expressly cover SOEs as well as examples of good practices from several States.

\subsection{Soft Law Initiatives Expressly Covering SOEs}

Firstly, the United Nations Guiding Principles on Business and Human Rights (UNGPs) have specific provisions that address SOEs from three perspectives, under the terminology 'the State-business nexus', in Principles 4, 5, and $6{ }^{84}$ The first perspective of the State-business nexus is covered by Principle 4 and addresses the State's ownership function directly and indirectly. Under Principle 4 States 'should take additional steps to protect against human rights abuses by businesses that are owned or controlled by the State, or that receive substantial support and services from State agencies'. Principle 5 of the UNGPs provides the second perspective on the State-business nexus and clarifies that just because a State may have privatized the delivery of key services that 'may have an impact on the realisation of human rights,' this does not mean that a State's obligation to continue to regulate and supervise those entities ends at the moment of privatization. States' obligations to regulate industries continue after privatization. ${ }^{85}$ The third perspective on the State-business nexus is dealt with in Principle 6 of the UNGPs and covers the totality of the commercial transactions in which a State may enter, such as procurement activities as well as other similar activities. Another issue that must be taken into consideration are the provisions of Principles 8, 9, and 10, which call for the need to ensure policy coherence at all levels within a State. A well-defined role for government departments, agencies, and other institutions that shape business practices in the area of business and human rights is thus paramount and policy coherence is needed both vertically and horizontally. Vertical policy coherence means ensuring that States have the necessary 'policies, laws, and processes to implement their international human rights obligations,' while horizontal policy coherence means 'supporting and equipping departments and agencies, at both the national and sub-national levels, that shape business practices' ${ }^{86}$ Consequently, policy coherence must also be ensured between the public and the private sector. The fact that SOEs should be a 'model' corporate citizen has also been emphasized

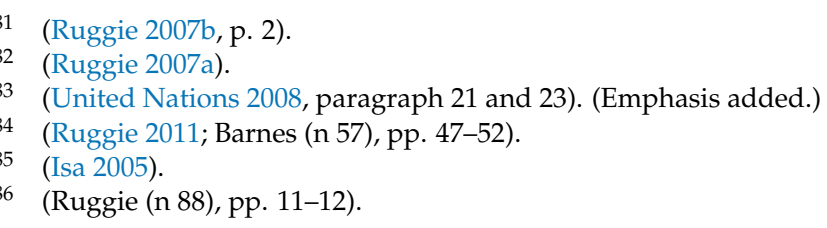


many times. ${ }^{87}$ The United Nations Working Group on Business and Human Rights has recently recommended to States that they introduce human rights due diligence into their procurement policies in order to support SDG target 12.7 on sustainable public procurement and into the development of finance trade support and export credit practices, ${ }^{88}$ an important issue given that State bureaucracies are some of the largest consumers of goods and services. ${ }^{89}$

Secondly, the Extractive Industries Transparency Initiative (EITI) has specific provisions concerning SOEs, since in many countries ${ }^{90}$ they play a major role in the management, regulation, and operation of the resources sector. ${ }^{91}$ Applicable only to States, the Extractive Industries Transparency Standard (EITI Standard) is an international standard for transparency, whose main purpose is to promote openness, accountability, and good governance in the extractive industry sector. ${ }^{92}$ The EITI Standard is composed of the EITI Principles, the EITI Requirements for Implementing Countries, the Validation Overview, and the Protocol for Participation of the Civil Society. ${ }^{93}$ As of March 2019, there were 51 member States. ${ }^{94}$ The concept of sustainable development is expressly mentioned in the EITI Standard. ${ }^{95}$ For instance, Principle 1 of the EITI Standard states that wealth generated from natural resources 'should be an important engine for sustainable economic growth that contributes to sustainable development and poverty reduction'. ${ }^{96}$ Principle 4 recognizes that 'a public understanding of government revenues and expenditures over time could help public debate and inform choice of appropriate and realistic options for sustainable development'. ${ }^{97}$ Requirement 2.6 deals with State participation in the extractive industries and obliges countries to disclose and explain the rules and practices that govern the relationship between the government and SOEs. Detailed information about the level of ownership, going all the way down to subsidiary and joint venture levels is also required. ${ }^{98}$ Any changes in the level of ownership or any other related transactions must be disclosed (Requirements 2.6(b) and 4.5). Revenues collected in-kind must also be disclosed (Requirement 4.2), as are any revenues from the transportation of oil, gas, and minerals (Requirement 4.4.) The distribution of revenues from extractive industries is dealt with under Requirement 5.1(a) and an explanation must be made if the revenues are recorded in the national budget. If the revenues are not recorded in the national budget a reason for why this is the case must be given. For the purposes of the EITI, a SOE is defined as a 'wholly or majority government-owned company that is engaged in extractive activities on behalf of the government'. ${ }^{99}$ Nevertheless, Requirement 2.6(a) acknowledges the scope of definitional variation at the domestic level and suggests that national laws and government structures are taken into account in the application of the definition. The disclosure of information related to social expenditures and the impact of the extractive sector on the economy is covered by Requirement 6, which covers both privately-owned companies and SOEs. For example, under Requirement 6.2, implementing countries must include disclosures from SOEs on their quasi-fiscal expenditures. ${ }^{100}$ The application of this article has potentially wide ramifications. For example, the top ten major Chinese

\footnotetext{
(Leading by Example: The State 2016).

(UN Working Group on Business and Human Rights (n 39), p. 3).

(Institute for Human Rights and Business 2015; Methven O'Brien and Martin-Ortega 2018).

(The World Bank: Raw Materials Group n.d., Appendix 2).

(EITI International Secretariat 2018; Rodrigues and Dieleman 2018).

(EITI International Secretariat 2016b).

ibid p. 10.

(EITI International Secretariat 2018).

5 (EITI International Secretariat 2016b). See in this context the Preamble, Principle 1, Principle 4, Requirement 7 and the Protocol on the participation of the civil society page 42.

96 (ibid p. 11; Shapiro et al. 2018; Narula 2018).

97 (EITI International Secretariat 2016b, p. 11); (State-Owned Enterprises Must Be 'Role Model' in Respecting Human Rights-UN Report 2016).

98 ibid 22.

99 ibid Requirement 2.6

100 In accordance with Requirement 6.2 quasi-fiscal expenditures include 'arrangements whereby SOEs undertake public social expenditure such as payments for social services, public infrastructure, fuel subsidies and national debt servicing, etc. outside of the national budgetary process'.
} 
companies operating in EITI-implementing countries are State-owned. ${ }^{101}$ A recent EITI Report shows that there is not much difference in reporting between Chinese companies and companies from other countries. ${ }^{102}$ Chinese companies now report in at least 24 of the 44 EITI implementing countries and there does not appear to be any cases in which a company from China has refused to collaborate with an implementing State concerning their reporting obligations. ${ }^{103}$ This shows that China, even if it is currently still not an EITI implementing State, has nevertheless made a commitment to transparency, to a certain extent. Since SOEs are some of the largest participants in the extractive industries sector, the EITI standard has the potential to not only increase transparency in a sector often considered opaque, but also to directly require that SOEs directly contribute to social expenditures in the host State. The EITI standard has remarkable future potential as far as the SDGs are concerned, given that the some of the most resource-rich countries in the world are often not only the poorest, but also have the largest governance gaps in terms of human rights and transparency. ${ }^{104}$

Thirdly, the OECD Guidelines for Multinational Enterprises (OECD Guidelines) ${ }^{105}$ and the OECD Guidelines on the Corporate Governance of State-owned Enterprises (OECD Guidelines for SOEs) $)^{106}$ also contain specific provisions that concern SOEs and sustainable development. The OECD Guidelines are applicable to all multinational enterprises, while the OECD Guidelines for SOEs seek to address the particular challenges concerning the corporate governance of SOEs, such as transparency, management, and corruption. Nevertheless, the OECD Guidelines make it clear that their provisions are also applicable to SOEs and underline the fact that SOEs are 'subject to the same recommendations as privately-owned enterprises, but public scrutiny is often magnified when the State is the final owner'. ${ }^{107}$ This indicates that the two instruments should be read together. The OECD Guidelines are recommendations 'addressed by governments to multinational enterprises operating in or from adhering countries, and which encourage businesses to behave in a responsible manner by respecting national laws and internationally agreed standards' ${ }^{108}$ Since the 2011 revision of the OECD Guidelines, human rights are expressly integrated in a separate chapter which mentions the UNGPs and the 'protect, respect, remedy' framework. ${ }^{109}$ The concept of sustainable development is also mentioned in the OECD Guidelines from various perspectives, such as environmental protection and the importance of science and technology. ${ }^{110}$ The Commentary on the General Policies broadly states the following:

There should not be any contradiction between the activity of multinational enterprises (MNEs) and sustainable development, and the Guidelines are meant to foster complementarities in this regard. Indeed, links among economic, social and environmental progress are a key means for furthering the goal of sustainable development. ${ }^{111}$

The OECD Guidelines for SOEs seek to address the challenges concerning the corporate governance of SOEs. However, they also contain a chapter on stakeholder relations and responsible business, which make certain recommendations for SOEs 'to observe high standards of responsible business conduct', with regard to the environment, employees, public health and safety, and human

101 China Metallurgical Group Corporation, China Minmetals, China Nonferrous Metal Mining Group, China Railway Corporation, China National Offshore Oil Corporation, China National Petroleum Corporation, PetroChina Company, Sinochem, Sinopec, Zijn Mining. All of those companies are either fully or in majority State-owned.

102 (EITI International Secretariat 2016a).

103 ibid.

104 (Wenar 2015, p. 127).

105 (OECD Guidelines for Multinational Enterprises 2011).

106 (OECD Guidelines on Corporate Governance of State-Owned Enterprises 2015).

107 (OECD Guidelines for Multinational Enterprises 2011, pp. 22, 29, 48).

108 ibid 3.

109 ibid 31-34.

110 ibid 13-15, 19, 21, 23, 30, 42, 44, 55, 69.

111 ibid 21. 
rights, and refer specifically to the standards of the OECD Guidelines, the ILO Tripartite Declaration concerning Multinational Enterprises, and the UNGPs. ${ }^{112}$ The OECD Guidelines for SOEs aim to 'devise a robust model for the ideal State shareholder' and 'seek to support economic efficiency, sustainable growth, and financial stability by rationalizing relationships between a company's management, board shareholders, and stakeholders' ${ }^{113}$ On the one hand, the Guidelines for SOEs are non-binding recommendations with no implementation or monitoring mechanisms. Consequently, governments that have a significant share of ownership in their economies may or may not adhere to them. Overall, their purpose is to insulate SOEs institutionally from day-to-day political interference'. ${ }^{114}$ On the other hand, the OECD Guidelines are binding on the countries that adhere to them, which ultimately means that their soft nature could be hardened in the future through national laws and international commitments. ${ }^{115}$ A clear illustration of the way such provisions may be hardened through international commitments is the increase in the references made to sustainable development and responsible businesses practices in international investment agreements. A recent empirical study, which analyzed over 2107 investment treaties, indicates that the inclusion of sustainable development and responsible business conduct language in international investment treaties has become a 'dominant treaty practice in recent years'. ${ }^{116}$ More than three quarters of international investment treaties conducted between 2008 and 2013, and virtually all of the international investment agreements conducted in 2012 and 2013, contained such language. ${ }^{117}$ However, the older treaties that do not have language to this effect still dominate the treaty sample and, overall, only $12 \%$ of international investment agreements contain this type of language. ${ }^{118}$ Other ways in which soft law requirements could be hardened at domestic level is through the adoption of national legislation. The Modern Slavery Act 2015 in the United Kingdom ${ }^{119}$ and the French Duty of Vigilance Law are relevant examples. ${ }^{120}$ Specific measures taken by States in the context of the State-business nexus will be examined separately, below in Section 5 .

\section{Good Practices on the Contribution of SOEs to the Promotion and Implementation of SDGs}

The purpose of this section is to demonstrate how the adoption of policies, followed by adequate implementation and monitoring mechanisms at domestic levels, have the potential to turn SOEs into key actors in the promotion and implementation of the SDGs. The policies adopted by Sweden, China, Spain, Finland, and Norway will be examined as examples of good practice. It is, however, acknowledged that there are many other States where SOEs and State ownership play an important role in the economy. The present choice of countries was mainly dictated by the availability of data, the importance of State ownership in that particular State, and also by space constraints.

\subsection{The Swedish State Ownership Policy}

The Nordic States have some of the most well developed policies concerning the implementation of the 2030 Agenda for Sustainable Development. The Nordic Strategy for Sustainable Development was the first macro-regional strategy where all the Ministers for Nordic Cooperation renewed their commitment on cooperation towards sustainable development and tasked the Nordic Expert Group for Sustainable Development with the development of a specific program designed specifically for

\footnotetext{
12 (OECD Guidelines on Corporate Governance of State-Owned Enterprises 2015, p. 60.)

13 (Rajavuori 2018, pp. 3, 10).

114 ibid 12.

115 (OECD Guidelines for Multinational Enterprises 2011, p. 13).

116 (Gordon et al. 2014, pp. 5-6).

117 ibid.

118 ibid. ('The issue most often addressed being environmental protection (10\%), followed by labour standards (5.5\%), anti-corruption $(1.5 \%)$ and human rights $(0.5 \%)$.

119 (Modern Slavery Act 2015 n.d.).

120 (LOI N²017-399 Du 27 Mars 2017).
} 
Nordic States. ${ }^{121}$ Sweden reports in detail the progress of its SOEs concerning the implementation of Agenda 2030. ${ }^{122}$ Adopted on 22 December 2016, 'The State's Ownership Policy and Guidelines for State-Owned Enterprises' (Policy) applies as of 1 January 2017. Sweden's State Ownership Policy has business sustainability at its core and it expressly states that:

State-owned enterprises should take a long-term approach, be efficient and profitable while being given the capacity to develop. To promote long-term sustainable value growth in state-owned enterprises, sustainable business is integrated into corporate governance. State-owned enterprises should thus serve as role models in the area of sustainable business and otherwise act in a manner that generates public confidence. ${ }^{123}$

The Policy expressly integrates the Global Compact, the UNGPs, the OECD Guidelines, as well as the goals of Agenda $2030^{124}$ and emphasizes the importance that SOEs work towards achieving a healthy work environment, respect for human rights, decent working conditions, environmental sustainability, and high standards of business ethics (particularly through the prevention of corruption), as well as responsible conduct with respect to the payment of taxes. ${ }^{125}$ The Policy forms an inherent part of the legal framework for the regulation of State-owned enterprises and it is mandatory for all companies that are fully or majority owned by the State to comply with it. ${ }^{126}$ Sweden has also undertaken to engage in a policy of dialogue with other companies, where it is a minority shareholder, in order to ensure that the Policy is applied in those cases as well. The ultimate responsibility for the integration of sustainable business practices into SOEs falls onto the board of directors. With regard to implementation, all SOEs have mandatory reporting obligations and the board of directors must ensure that sustainability reporting is done in a comprehensive and transparent manner. Disclosure must be made on the company website and the reports must include, among others, materiality analyses, appropriate sustainability disclosures, and clear information about stakeholder engagement. ${ }^{127}$

By way of example, Vattenfall, one of the largest Swedish State-owned enterprises, which is also one of Europe's largest producers of heat and electricity, has used comprehensive disclosure in the 2016 Annual Report that covers its relationship with stakeholders, responsible sourcing, its human rights and taxation policies, and environment policies. ${ }^{128}$ In its 2016 Annual Report, Vattenfall disclosed that it was faced with pressure from NGO groups to stop sourcing coal from Colombian companies that could be complicit to human rights abuses. Vattenfall did not divest from those companies, but it has undertaken to work with local suppliers involved in the peace and reconciliation process. The company has also confirmed that it had engaged in due diligence to ensure that the countries in which it operates adhere to the ILO's eight fundamental conventions, it had revised its Code of Conduct for Suppliers, and that it had issued a statement on slavery and human rights in order to comply with Section 54 of the UK Modern Slavery Act 2015. ${ }^{129}$

\subsection{The Chinese State Ownership Policy}

The State ownership policy adopted by the Chinese government is particularly important in the context of this article. This is because China has some of the largest and most important SOEs. ${ }^{130}$

121 (Mikko et al. 2017, p. 8). As outlined in this Report, any references to 'Nordic States' in this article is taken to include Denmark, Finland, Iceland, Norway, Sweden, Faroe Islands, Greenland, and Åland.

122 (Government of Sweden 2017, pp. 58-60).

123 (Government of Sweden, Ministry of Enterprise and Innovation n.d., p. 2).

124 ibid 4.

125 (ibid; Government of Sweden (n 71), p. 27).

126 (Government of Sweden (n 71), p. 15).

127 (Government of Sweden, Ministry of Enterprise and Innovation n.d., pp. 8-9).

128 (Vattenfall 2016, pp. 157-166).

129 (Vattenfall 2017).

130 (Kwiatkowski and Augustynowicz (n 55). 
Another matter to be taken into consideration is that China has been criticized for a considerable amount of time for its poor environmental and human rights records, ${ }^{131}$ so the overall efforts undertaken to establish a 'responsible public image' have been extensive. ${ }^{132}$ Many of the measures designed so far are intended to address not only the specific operations and on-the-ground activities of various State-owned enterprises, but also the passive investment activities of many other entities that are associated with the State. All SOEs in China are supervised and administered by the State-owned Assets Supervision and Administration Commission of the State Council (SASAC). The SASAC is an institution under the direct management of the State Council, charged with the supervision and management of all centrally administered State-owned enterprises, excluding financial enterprises. ${ }^{133}$ In its role as a central administrator, the SASAC has issued Guidelines to the State-Owned Enterprises, directly under the Central Government, on fulfilling corporate social responsibilities (Guidelines). ${ }^{134}$

As overarching principles, the Guidelines restate that State-owned enterprises are 'the backbone' of China's economy, that they 'have a vital bearing on national security', and that fulfilling corporate social responsibility is not only their mission, but also 'an ardent expectation and requirement from the public' and a prerequisite in order to participate in economic cooperation' ${ }^{135}$ The core parts of the Guidelines are concerned with the content of corporate social responsibility, as understood in China, and the taking of various practical measures in order to fulfill those requirements. Overall, corporate social responsibility is understood to mean the necessity of taking various measures in eight distinct areas, as follows: The necessity to operate in a legal and honest way; the need to improve internal corporate governance in order to increase efficiency, competitivity, and to ensure cost minimization; the requirement to ensure continuous improvement of product quality and service; the need to strengthen resource conservation and environmental protection by upgrading their technology and equipment; the promotion of independent innovation and technological advancement; the need to ensure production safety; the protection of the legal rights of employees and participation in social public welfare programs ${ }^{136}$. Overall, the Guidelines do not use terminology such as 'human rights' or 'business and human rights'. A survey conducted on the human rights practices of Chinese companies generally showed that Chinese companies recognize fewer rights but, among the rights recognised, support is given mainly to labour rights and the right to development, while other civil, political, and social rights are given less support. ${ }^{137}$ Despite those findings, Chinese State-owned enterprises recognised human rights at a higher level than the Chinese private sector ${ }^{138}$ and they have pioneered corporate social responsibility reporting and the adoption of corporate social responsibility reporting standards, such as the Global Reporting Initiative Sustainability Reporting Guideline, the ISO 2600 Standards, and other similar industry-specific initiatives, since the mid-2000s. ${ }^{139}$ China has also issued a third National Human Rights Action Plan of China (2016-2020). ${ }^{140}$ While the National Action Plan does not expressly include a separate section on business and human rights, some commentators

131 (Human Rights Watch 2011).

132 (Zhu 2017; Xu et al. 2017; Shahab et al. 2018; Qiu 2017; Marquis et al. 2017; Marquis and Qian 2014; Guttman et al. 2018; Aidoo et al. 2017).

133 SASAC performs the following functions: 'supervises and manages the State-owned assets of centrally administered State-owned enterprises'; it is responsible for the supervision and for ensuring the increase in the value of State-owned assets; it takes charge of the reform and restructuring of State-owned enterprises; it appoints and removes the top executives of the entities supervised; it manages the day-to-day operation of the supervisory panels; takes charge of the State-owned capital operational budget and ensures that surplus capital is returned to the State; it ensures that the supervised enterprises apply relevant legislation, regulation and principles; and it takes charge of the 'fundamental management' of those entities.

134 (Guidelines to the State-Owned Enterprises Directly under the Central Government n.d.).

135 ibid.

136 ibid.

137 (Harvard University 2007, p. 1).

138 (ibid; Whelan and Muthuri 2017).

139 (Li and Belal 2018, pp. 199, 202-204).

140 (National Human Rights Action Plan of China (2016-2020) n.d.). 
believe that it may ultimately play this role, since it introduces a human rights education plan and guidance for implementing human rights due diligence in investment and foreign aid' ${ }^{141}$

There are other similar measures concerning the investment activities of all Chinese businesses. The Ministry of Commerce and the Ministry of Environmental Protection have issued a Guidance on Environmental Protection in Foreign Investment Cooperation, which requires enterprises operating abroad to 'establish' the concept of environmental protection internally, to fulfill social responsibility for environmental protection, to respect the religions and customs of the host country, to pay adequate consideration to labour concerns, to respect the environmental protection laws of the host country, to perform environmental impact assessments throughout the project, and to 'study and learn' from the standards and practices of international organizations and multilateral financial institutions. ${ }^{142}$ The China Banking and Regulatory Commission has issued the Green Credit Guidelines, which require banks financing overseas investment to strengthen environmental and corporate social responsibility requirements. ${ }^{143}$ The Green Credit Guidelines cover 'policy banks and State-owned commercial banks'. Article 21 of the Green Credit Guidelines requires banks to ensure that the businesses they lend to respect the host State's laws and regulations concerning the environment and 'make a promise in public that appropriate international practices or international norms will be followed'. With regard to sustainable development, Article 6 mandates the board of directors or the supervisory board to 'promote green credit concepts concerning energy saving, environmental protection, and sustainable development ... that will benefit society'. ${ }^{144}$ Some other sector specific instruments, however, such as the Guidelines for Social Responsibility in Outbound Mining Investments expressly incorporate the UNGPs and state that those companies 'observe the UN Guiding Principles on Business and Human Rights during the entire lifecycle of the mining project' ${ }^{145}$ The China Chamber of Commerce of Metals, Minerals and Chemical Importers and Exporters entered into a formal agreement with the International Council on Mining and Metals in late 2017 to 'help promote sustainable development in Chinese companies' overseas mining investment'. ${ }^{146}$ The National Plan on the implementation of Agenda 2030 and the 2017 Report on the Sustainable Development of Chinese Enterprises Overseas outline the actions that China is planning to undertake over the next 15 years, towards the promotion of the SDGs. The National Plan on the Implementation of Agenda 2030 also deals with the interlinkages between Agenda 2030 and the proposed Belt and Road Initiative. ${ }^{147}$

\subsection{Other States}

Other States have adopted similar measures. For example, Spain's Sustainable Economy Law of 2011 requires SOEs to file annual corporate governance reports and sustainability reports. ${ }^{148}$ Finland, which has the largest market capitalization of SOEs relative to GDP, has recently issued a Government Resolution on State Ownership Policy, requiring SOEs, listed or unlisted, to report

141 (China Releases 3rd National Human Rights Action Plan n.d.; Danish Institute for Human Rights and Universal Rights Group (n 29), p. 8).

142 (MOFCOM and MEP Jointly Issued Guidance on Environmental Protection in Foreign Investment and Cooperation n.d.; Barnes (n 57), pp. 24-25).

143 (Notice of the CBRC on Issuing the Green Credit Guidelines n.d.).

144 ibid.

145 (China Chamber of Commerce of Metals 2014, pp. 34-36).

146 (ICMM • Chinese Mining Body Aligns with ICMM to Promote Mining with Principles n.d.).

147 (China's National Plan on Implementation of the Agenda 2030 2016, pp. 26-72; Chinese Academy of International Trade and Economic Cooperation et al. 2017).

148 (Ley No 2/2011 de 4 de Marzo de 2011). Article 39(2) provides that: 'El conjunto de características, indicadores y modelos de referencia a que se refiere el apartado anterior deberá atender especialmente a los objetivos de transparencia en la gestión, buen gobierno corporativo, compromiso con lo local y el medioambiente, respeto a los derechos humanos, mejora de las relaciones laborales, promoción de la integración de la mujer, de la igualdad efectiva entre mujeres y hombres, de la igualdad de oportunidades y accesibilidad universal de las personas con discapacidad y del consumo sostenible, todo ello de acuerdo con las recomendaciones que, en este sentido, haga el Consejo Estatal de la Responsabilidad Social Empresarial, constituido por el Real Decreto 221/2008, de 15 de febrero, por el que se regula el Consejo Estatal de Responsabilidad Social de las Empresas'. 
their sustainability performance in a comprehensive manner. ${ }^{149}$ Norway has adopted a similar stance. As such, the official aim of the Norwegian Government is for its State-ownership 'to be an example of best practice internationally'. ${ }^{150}$ The main legal framework for State-ownership in Norway is provided by constitutional arrangement, which ultimately delegates the administration of the various SOEs to the corresponding ministry. 'The Ministers' powers of administration are exercised under constitutional and parliamentary responsibility'. ${ }^{151}$ Apart from the constitutional framework, Norway's State ownership policy is organized to comply with other national legislation, such as competition law, stock exchange trading, corporate governance rules, and the various EU rules pertaining to State aid. The OECD Guidelines for SOEs are actively incorporated and apply to all companies that are State-owned. ${ }^{152}$ There are also 10 Principles of Corporate Governance that have been developed by the Government and of particular interest are Principles 2 and 10. Principle 2 expressly acknowledges that a high-degree of transparency should underpin the activities of all SOEs. ${ }^{153}$ Principle 10 states that SOEs 'shall work systematically to safeguard their corporate social responsibility'. The Government expects SOEs to deliver not only exclusively on financial targets but also to act as 'exemplary' corporate citizens in four key areas, climate and the environment, human rights, employee and worker rights, and anti-corruption ${ }^{154}$ The UNGPs are also expressly incorporated in the Government's State Ownership Policy. There is a clear expectation from all SOEs to ensure that human rights are respected in their own operations, as well as by their business partners. ${ }^{155}$ SOEs are also required to carry out human rights due diligence. All businesses, public and private, are expected to be familiar with the provisions of the core ILO Conventions. ${ }^{156}$ Later initiatives, such as the creation of the Norwegian National Action Plan for Business and Human Rights ${ }^{157}$ and the integration of the UNGPs into the investment policy of Norges Bank, the world's largest sovereign wealth fund, ${ }^{158}$ add further complexity to this regulatory landscape.

\section{Conclusions}

This paper discusses SOEs in light of Agenda 2030. While the private sector has a key role to play in the promotion and implementation of Agenda 2030, SOEs are also important actors in this context. By virtue of the connection with the State that owns them, SOEs could be mobilized as 'resources' available to States for the promotion and implementation of the SDGs. An analysis of the State ownership policies of several States shows that some States have made significant progress in this area and have adopted specific policies concerning the promotion and implementation of the SDGs in SOEs. Those policies could constitute an example of good practice for other States that have not yet made progress in this area. By focusing on SOEs, rather than the private sector, overall, this paper rebalances the discourse about the important role that all business enterprises, regardless of whether their ownership is public or private, have in the promotion and implementation of the sustainable development goals enshrined in Agenda 2030.

Funding: This research received no external funding.

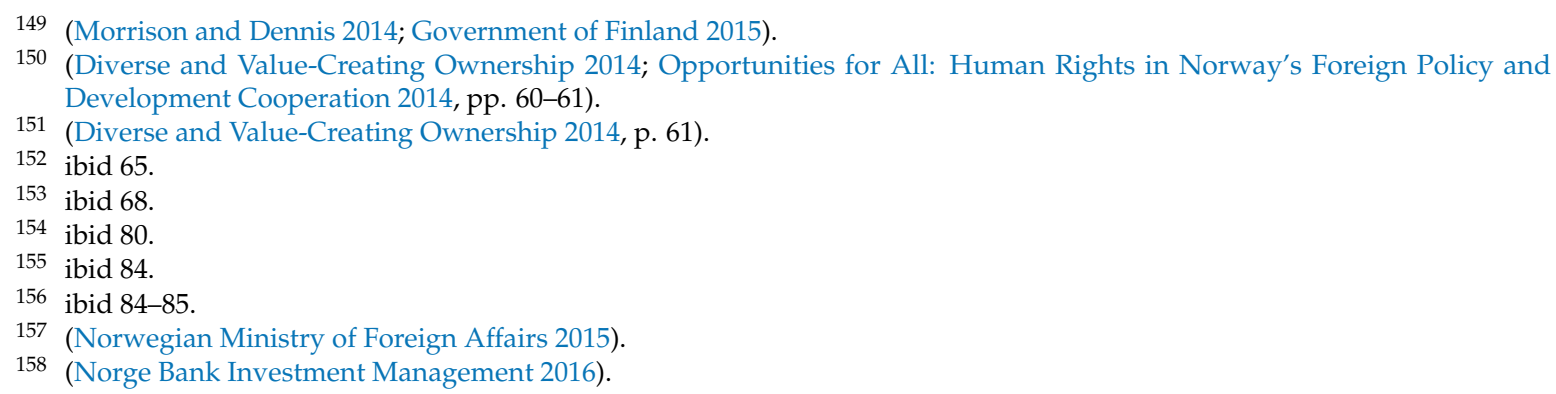


Acknowledgments: The author would like to thank the peer-reviewers for their comments and suggestions. Thank you also to Mara Tignino for her support and suggestions, which have significantly improved the final version of this article.

Conflicts of Interest: The author declares no conflict of interest.

\section{References}

Aidoo, Richard, Pamela Martin, Min Ye, and Diego Quiroga. 2017. Footprints of the Dragon: China's Oil Diplomacy and Its Impacts on Sustainable Development Policy in Ecuador and Ghana. Revue Internationale de Politique de Développement 8: 1. [CrossRef]

Arts, Karin. 2017. Inclusive Sustainable Development: A Human Rights Perspective. Current Opinion in Environmental Sustainability 24: 58-62. [CrossRef]

Backer, Larry Catá. 2008. The Private Law of Public Law: Public Authorities as Shareholders, Golden Shares, Sovereign Wealth Funds, and the Public Law Element in Private Choice of Law. Tulane Law Review 82: 1801.

Backer, Larry Cata. 2010. Sovereign Investing in Times of Crisis: Global Regulation of Sovereign Wealth Funds, State-Owned Enterprises, and the Chinese Experience. Transnational Law \& Contemporary Problems 19: 3.

Backer, Larry Cata. 2016. Between State, Company, and Market: A Preliminary Engagement on the Business and Human Rights Obligations of States and State Owned Enterprises (SOEs). Working Papers Coalition for Peace and Ethics (Number 11-1, November 2016). Available online: https: / ssrn.com/abstract=2869944 (accessed on 15 January 2017).

Backer, Larry Catá. 2017. The Human Rights Obligations of State-Owned Enterprises (SOEs): Emerging Conceptual Structures and Principles in National and International Law and Policy. Vanderbilt Journal of Transnational Law 50: 1.

Balakrishnan, Radhika, Diane Elson, James Heintz, and Nicholas Lusiani. 2011. Maximum Available Resources $\mathcal{E}$ Human Rights: Analytical Report. Rutgers: The State University of New Jersey, Center for Women's Global Leadership.

Barnes, Mihaela Maria. 2018. The United Nations Guiding Principles on Business and Human Rights, the State Duty to Protect Human Rights and the State-Business Nexus. Brazilian Journal of International Law 15: 42-65. [CrossRef]

Barral, V. 2012. Sustainable Development in International Law: Nature and Operation of an Evolutive Legal Norm. European Journal of International Law 23: 377-400. [CrossRef]

Büge, Max, Monika Sztajerowska, Matias Egeland, and Przemyslaw Kowalski. 2013. State-Owned Enterprises: Trade Effects and Policy Implications. OECD Trade Policy Papers 147. Available online: http:/ /www.oecdilibrary.org/trade/state-owned-enterprises_5k4869ckqk7l-en (accessed on 29 September 2016).

Can, Özgür, and Sara L. Seck. 2006. The Legal Obligations With Respect to Human Rights and Export Credit Agencies-June 23, 2006 I Halifax Initiative. Available online: http:/ / www.halifaxinitiative.org/content/ legal-obligations-respect-human-rights-and-export-credit-agencies-june-23-2006 (accessed on 20 June 2018).

China Chamber of Commerce of Metals, Minerals \& Chemicals Importers \& Exporters. 2014. CCMCMC Guidelines for Social Responsibility in Outbound Mining Investments. Available online: http:/ /csr2.mofcom.gov.cn/ article/policies/ind/201812/20181202819524.shtml (accessed on 16 October 2014).

China Releases 3rd National Human Rights Action Plan (2016-2020), Includes Few Elements on Business \& Human Rights|Business \& Human Rights Resource Centre. n.d. Available online: https:/ / www.business-humanrights.org/en/china-releases-3rd-national-human-rights-action-plan2016-2020-includes-few-elements-on-business-human-rights (accessed on 12 October 2018).

China's National Plan on Implementation of the Agenda 2030. 2016. Available online: https:/ /www.fmprc.gov. cn/mfa_eng/zxxx_662805/W020161014332600482185.pdf (accessed on 12 October 2018).

Chinese Academy of International Trade and Economic Cooperation, SASAC Research Centre, and United Nations Development Programme China. 2017. Report on the Sustainable Development of Chinese Enterprises Overseas: Supporting the Belt and Road Regions to Achieve the 2030 Agenda for Sustainable Development. Available online: images.mofcom.gov.cn/csr2/201708/20170808151845532.pdf (accessed on 14 October 2018). 
Committee on the Elimination of Discrimination against Women. 2016. Committee on the Elimination of Discrimination against Women (CEDAW)—Submission to the HLPF 2016. United Nations. Available online: https: / / sustainabledevelopment.un.org $/$ index.php?page=view\&type=30022\&nr=108\&menu=3170 (accessed on 11 October 2018).

Danish Institute for Human Rights, and Universal Rights Group. 2017. Human Rights and the SDGs: Pursuing Synergies. Available online: https:/ / www.universal-rights.org/urg-policy-reports/human-rightssustainable-development-goals-pursuing-synergies/ (accessed on 11 October 2017).

Danish Institute for Human Rights. 2018. Human Rights and the 2030 Agenda for Sustainable Development: Lessons Learned and Next Steps. Available online: https:/ / www.humanrights.dk/publications/humanrights-2030-agenda-sustainable-development-lessons-learned-next-steps (accessed on 11 October 2018).

Diverse and Value-Creating Ownership. 2014. Meld. St. 27 (2013-2014) Report to the Storting (White Paper) Recommendation of the Ministry of Trade, Industry and Fisheries of 20 June 2014, approved in the Council of State the same day. (The Solberg Government). Available online: https://www.regjeringen.no/en/ dokumenter/meld.-st.-27-2013-2014/id763968/ (accessed on 3 May 2018).

Dommen, Caroline. 2017. Obligation to Mobilize Resources: Bridging Human Rights, Sustainable Development Goals and Economic and Fiscal Policies. International Bar Association, Human Rights Institute. Available online: https://www.ibanet.org/Human_Rights.../HRI.../Obligation-to-Mobilise-Resources.aspx (accessed on 5 October 2018).

EITI International Secretariat. 2016a. Chinese Companies Reporting in EITI Countries: Review of the Engagement of Chinese Firms in Countries Implementing the EITI. Available online: https: / / eiti.org/document/ eiti-briefchinese-companies-reporting-in-eiti-implementing-countries\#DownloadPDF (accessed on 24 January 2017).

EITI International Secretariat. 2016b. The EITI Standard 2016. Available online: https:/ / eiti.org/document/eitistandard-requirements-2016 (accessed on 3 October 2018).

EITI International Secretariat. 2018. Extractive Industries Transparency Initiative: Progress Report 2018. Available online: https: / / eiti.org/ (accessed on 11 October 2018).

Feiring, Brigitte, and Adrian Hassler. 2016. Human Rights in Follow-Up and Review of the 2030 Agenda for Sustainable Development. Danish Institute for Human Rights. Available online: https:/ /www.humanrights. $\mathrm{dk}$ / publications/human-rights-follow-review-2030-agenda-sustainable-development (accessed on 6 October 2018).

Gabčíkovo-Nagymaros Project (Hungary/Slovakia). n.d. Judgment, I.C.J. Reports 1997. p. 7. Available online: https://www.icj-cij.org/en/case/92/judgments (accessed on 7 April 2019).

Gang, Fan. 2013. The Role of State-Owned Enterprises in the Chinese Economy. China US Focus. Available online: https: / www.chinausfocus.com/2022/wp-content/uploads/Part+02-Chapter+16.pdf (accessed on 18 October 2018).

Gianturco, Delio E. 2001. Export Credit Agencies: The Unsung Giants of International Trade and Finance. Santa Barbara: Greenwood Publishing Group.

Giné-Garriga, Ricard, Óscar Flores-Baquero, Alejandro Jiménez-Fdez de Palencia, and Agustí Pérez-Foguet. 2017. Monitoring Sanitation and Hygiene in the 2030 Agenda for Sustainable Development: A Review through the Lens of Human Rights. Science of The Total Environment 580: 1108-19. [CrossRef]

Gordon, Kathryn, Joachim Pohl, and Marie Bouchard. 2014. Investment Treaty Law, Sustainable Development and Responsible Business Conduct: A Fact Finding Survey. Paris: OECD Publishing.

Government of Finland. 2015. Government Ownership Steering: Financial Annual Report 2015. Available online: vnk.fi/government-ownership-steering (accessed on 16 January 2018).

Government of Sweden. 2016. Annual Report on State-Owned Enterprises 2016. Available online: https: / / www.government.se/reports/2017/09/annual-report-state-owned-enterprises-2016/ (accessed on 21 September 2018).

Government of Sweden. 2017. Sweden and the 2030 Agenda: Report to the UN High Level Political Forum 2017 on Sustainable Development. Available online: https://www.government.se/reports/2017/06/swedenand-the-2030-agenda--report-to-the-un-high-level-political-forum-2017-on-sustainable-development/ (accessed on 21 September 2018).

Government of Sweden, Ministry of Enterprise and Innovation. n.d. The State's Ownership Policy and Guidelines for State-Owned Enterprises 2017. Available online: https:/ / www.government.se/reports/2017/06/thestates-ownership-policy-and-guidelines-for-state-owned-enterprises-2017/ (accessed on 11 January 2018). 
Guidelines to the State-Owned Enterprises Directly under the Central Government. n.d. Available online: http:/ / en.sasac.gov.cn/2011/12/06/c_313.htm (accessed on 4 February 2019).

Guttman, Dan, Oran Young, Yijia Jing, Barbara Bramble, Maoliang Bu, Carmen Chen, and Kathinka Furst. 2018. Environmental Governance in China: Interactions between the State and 'Nonstate Actors'. Journal of Environmental Management 220: 126-35. [CrossRef] [PubMed]

Hancock, Linda, Natalie Ralph, and Saleem Ali. 2018. Bolivia's Lithium Frontier: Can Public Private Partnerships Deliver a Minerals Boom for Sustainable Development? Journal of Cleaner Production 178: 551-60. [CrossRef]

Handbook for Preparation of Voluntary National Reviews. n.d. United Nations (Division for Sustainable Development, Department of Economic and Social Affairs). Available online: https:// sustainabledevelopment.un.org/.../20872VNR_hanbook_2019_Edition_v2.pdf (accessed on 12 October 2018).

Harris, David, O'Boyle Michael, Bates Ed, and Buckley Clara. 2014. Harris, O'Boyle \& Warbrick: Law of the European Convention on Human Rights, 3rd ed. Oxford: Oxford University Press.

Harvard University, John F. Kennedy School of Government. 2007. Human Rights Policies of Chinese Companies: Results from a Survey Conducted under the Mandate of the UN Secretary-General's Special Representative for Business and Human Rights Professor John G. Ruggie Harvard University. Available online: https: / / www.ohchr.org/en/issues/business/pages/reports.aspx (accessed on 17 February 2018).

Hernandez-Perdomo, Elvis A., Johnathan Mun, and Claudio M. Rocco S. 2017. Active Management in State-Owned Energy Companies: Integrating a Real Options Approach into Multicriteria Analysis to Make Companies Sustainable. Applied Energy 195: 487-502. [CrossRef]

Hults, David R., Mark C. Thurber, and David G. Victor, eds. 2012. Oil and Governance: State-Owned Enterprises and the World Energy Supply. Cambridge and New York: Cambridge University Press.

Human Rights Watch. 2011. 'You'll Be Fired If You Refuse': Labor Abuses in Zambia's Chinese State-Owned Copper Mines. Available online: https:/ / www.hrw.org/report/2011/11/04/youll-be-fired-if-you-refuse/ labor-abuses-zambias-chinese-state-owned-copper-mines (accessed on 23 February 2017).

ICMM • Chinese Mining Body Aligns with ICMM to Promote Mining with Principles. n.d. Available online: https:/ / www.icmm.com/en-gb/news/2017/icmm-signs-mou-with-cccmc (accessed on 12 October 2018).

Inkpen, Andrew, and Kannan Ramaswamy. 2018. State-Owned Multinationals and Drivers of Sustainability Practices: An Exploratory Study of National Oil Companies. In State-Woned. Edited by Sinziana Dorobantu, Ruth V. Aguilera, Jiao Luo and Frances J. Milliken. Bingley: Emerald Publishing Limited.

Institute for Human Rights and Business. 2015. Protecting Rights by Purchasing Right: The Human Rights Provisions, Opportunities and Limitations under the 2014 EU Public Procurement Directives. Available online: https:/ / www.ihrb.org/.../Occasional-Paper-3-Protecting-Rights-by-Purchasing-Right. pd... (accessed on 9 January 2018).

International Covenant on Civil and Political Rights. 1966. Available online: https://treaties.un.org/doc/ publication/unts / .../volume-999-i-14668-english.pdf (accessed on 15 October 2018).

International Covenant on Economic, Social and Cultural Rights. 1966. Available online: https://treaties.un.org/ doc/treaties/1976/01/.../ch_iv_03.pdf (accessed on 15 October 2015).

Isa, Felipe Gómez. 2005. Privatisation and Human Rights in the Age of Globalisation. Mortsel: Intersentia nv.

Kaufman, Riza. 2017. Localizing Human Rights in the United States through the 2030 Sustainable Development Agenda. Columbia Human Rights Law Review 49: 99-128.

KS, Jomo, Anis Chowdhury, Krishnan Sharma, and Daniel Platz. 2016. Public-Private Partnerships and the 2030 Agenda for Sustainable Development: Fit for Purpose? (Working Paper). New York: UN DESA.

Kwiatkowski, Grzegorz, and Pawel Augustynowicz. 2015. State-Owned Enterprises in the Global Economy-Analysis Based on Fortune Global 500 List. Paper presented at MakeLearn and TIIM Joint International Conference, Bari, Italy, May 27-29.

Lambin, Eric F., and Tannis Thorlakson. 2018. Sustainability Standards: Interactions Between Private Actors, Civil Society, and Governments. Annual Review of Environment and Resources 43: 369-93. [CrossRef]

Leading by Example: The State, State-Owned Enterprises and Human Rights (Report of the Working Group on the Issue of Human Rights and Transnational Corporations and Other Business Enterprises). 2016. Available online: https:/ / www.ohchr.org/en/issues/business/pages/reports.aspx (accessed on 17 February 2018).

Ley No 2/2011 de 4 de Marzo de 2011 Sobre Economía Sostenible (Modificada Por La Ley No 2/2012 de 29 de Junio de 2012). 2011. Available online: https:/ / www.boe.es/buscar/act.php?id=BOE-A-2011-4117 (accessed on 16 January 2018). 
Li, Teng, and Ataur Belal. 2018. Authoritarian State, Global Expansion and Corporate Social Responsibility Reporting: The Narrative of a Chinese State-Owned Enterprise. Accounting Forum 42: 199-217. [CrossRef]

LOI N ${ }^{\circ}$ 2017-399 Du 27 Mars 2017 Relative Au Devoir de Vigilance Des Sociétés Mères et Des Entreprises Donneuses d'ordre. 2017. Available online: https:/ /www.legifrance.gouv.fr/eli/loi/2017/3/27/2017-399/ jo/texte (accessed on 22 February 2018).

Lowe, Vaughan. 1999. Sustainable Development and Unsustainable Arguments. In International Law and Sustainable Development: Past Achievements and Future Challenges. Edited by Alan Boyle and David Freestone. Oxford: Oxford University Press.

Marquis, Christopher, and Cuili Qian. 2014. Corporate Social Responsibility Reporting in China: Symbol or Substance? Organization Science 25: 127-48. [CrossRef]

Marquis, Christopher, Juelin Yin, and Dongning Yang. 2017. State-Mediated Globalization Processes and the Adoption of Corporate Social Responsibility Reporting in China. Management and Organization Review 13: 167-91. [CrossRef]

McGoldrick, Dominic. 1996. Sustainable Development and Human Rights: An Integrated Conception. International and Comparative Law Quarterly 45: 796-818. [CrossRef]

Methven O'Brien, Claire, and Olga Martin-Ortega. 2018. Discretion, Divergence, Paradox: Public and Private Supply Chain Standards on Human Rights. SSRN Electronic Journal. [CrossRef]

Mikko, Halonen, Persson Åsa, Sepponen Susanna, Siebert Kehler Clarisse, Bröckl Marika, Vaahtera Anu, Quinn Shane, Trimmer Caspar, and Isokangas Antti. 2017. Sustainable Development Action-the Nordic Way: Implementation of the Global 2030 Agenda for Sustainable Development in Nordic Cooperation. Copenhagen: Nordic Council of Ministers.

Modern Slavery Act 2015. n.d. Available online: http:/ /www.legislation.gov.uk/ukpga/2015/30/contents / enacted (accessed on 22 February 2018).

MOFCOM and MEP Jointly Issued Guidance on Environmental Protection in Foreign Investment and Cooperation. n.d. Available online: http:/ / english.mofcom.gov.cn/article/newsrelease/significantnews / 201303/20130300043146.shtml (accessed on 4 February 2019).

Morrison, John, and Haley St. Dennis. 2014. State of Play: Human Rights in the Political Economy of States: Avenues for Application. London: Institute for Human Rights and Business.

Narula, Rajneesh. 2018. Multinational Firms and the Extractive Sectors in the 21st Century: Can They Drive Development? Journal of World Business 53: 85-91. [CrossRef]

National Human Rights Action Plan of China (2016-2020). n.d. Available online: http:/ / english.gov.cn/archive/ publications/2016/09/29/content_281475454482622.htm (accessed on 14 February 2019).

Norge Bank Investment Management. 2016. Human Rights Expectations towards Companies. Available online: https: / / www.nbim.no/contentassets/.../human-rights-expectations-document2.pdf (accessed on 12 January 2018).

Norwegian Ministry of Foreign Affairs. 2015. Business and Human Rights National Action Plan for the Implementation of the UN Guiding Principles. Available online: https://www.regjeringen.no/en/ dokumenter/business_hr/id2457944/ (accessed on 15 November 2018).

Notice of the CBRC on Issuing the Green Credit Guidelines. n.d. Available online: http:/ /www.cbrc.gov.cn/ EngdocView.do?docID=3CE646AB629B46B9B533B1D8D9FF8C4A (accessed on 4 February 2019).

Obligaciones estatales in relación con el medio ambiente en el marco de la protección y garantia de los derechos a la vida y la integridad personal-interpretación y alcance de los articulos 4.1 y 5.1, en recion con los articulos 1.1 y 2 de la convención Americana sobre derechos humanos. n.d. 102. Inter-American Court of Human Rights, Advisory Opinion OC 23/17, 15 November 2017 Available online: www.corteidh.or.cr/docs/ opiniones/seriea_23_esp.pdf (accessed on 21 March 2018).

OECD. 2011. OECD Guidelines for Multinational Enterprises, 2011 ed. Paris: OECD Publishing.

OECD. 2015. OECD Guidelines on Corporate Governance of State-Owned Enterprises. Paris: OECD Publishing.

Office of the High Commissioner for Human Rights. 2015. Transforming Our World: Human Rights in the 2030 Agenda for Sustainable Development. Available online: http:/ / www.ohchr.org/Documents / Issues/MDGs/ Post2015/HRAndPost2015.pdf (accessed on 12 October 2018).

Opportunities for All: Human Rights in Norway's Foreign Policy and Development Cooperation. 2014. Meld. St. 10 (2014-2015) Report to the Storting (white paper). Available online: https:/ / www.regjeringen.no/ contentassets/.../en.../stm201420150010000engpdfs.pdf (accessed on 12 January 2018). 
Park, Stephen Kim. 2018. Social Bonds for Sustainable Development: A Human Rights Perspective on Impact Investing. Business and Human Rights Journal 6: 1-23. [CrossRef]

Pulp Mills on the River Uruguay (Argentina v. Uruguay). n.d. Judgment, I.C.J. Reports 2010. p. 14. Available online: https:/ / www.icj-cij.org/en/case/135/judgments (accessed on 7 April 2019).

Qiu, Jennifer. 2017. Quality of CSR Reporting in China: A Comparative Analysis Between State- and Privately-Owned Real Estate Companies. Social Impact Research Experience (SIRE) 38: 1-38.

Rajavuori, M. 2015. How Should States Own? Heinisch v. Germany and the Emergence of Human Rights-Sensitive State Ownership Function. European Journal of International Law 26: 727-46. [CrossRef]

Rajavuori, Mikko. 2018. Governing the Good State Shareholder: The Case of the OECD Guidelines on Corporate Governance of State-Owned Enterprises. European Business Law Review 29: 103-42.

Rio Declaration on Environment and Development. 1992. Available online: http:/ /www.un.org/documents/ga/ conf151/aconf15126-1annex1.htm (accessed on 15 October 2018).

Ritchken, Edwin. 2014. The Evolution of State-Owned Enterprises in South Africa. Available online: https:/ / www. oecd.org/daf/ca/Workshop_SOEsDevelopmentProcess_SouthAfrica.pdf (accessed on 12 October 2018).

Rodrigues, Suzana B., and Marleen Dieleman. 2018. The Internationalization Paradox: Untangling Dependence in Multinational State Hybrids. Journal of World Business 53: 39-51. [CrossRef]

Ruggie, John Gerard. 2007a. State Responsibilities to Regulate and Adjudicate Corporate Activities under the United Nations Core Human Rights Treaties: An Overview of Treaty Body Commentaries (Report of the Special Representative of the Secretary-General on the Issue of Human Rights and Transnational Corporations and Other Business Enterprises). A/HRC/4/35/Add.1. Available online: https:/ /www.ohchr. org/en/issues/business/pages/reports.aspx (accessed on 15 October 2018).

Ruggie, John Gerard. 2007b. "State Responsibilities to Regulate and Adjudicate Corporate Activities under the United Nations' Core Human Rights Treaties (Report of the Special Representative of the Secretary-General on the Issue of Human Rights and Transnational Corporations and Other Business Enterprises)." John F. Kennedy School of Government. Available online: https:/ /www.ohchr.org/en/issues/business/pages/ reports.aspx (accessed on 15 October 2018).

Ruggie, John. 2011. “Guiding Principles on Business and Human Rights: Implementing the United Nations 'Protect, Respect and Remedy' Framework (Report of the Special Representative of the Secretary-General on the Issue of Human Rights and Transnational Corporations and Other Business Enterprises)." A/HRC/17/31. Available online: https://www.ohchr.org/en/issues/business/pages/reports.aspx (accessed on 15 October 2018).

Schutter, Olivier De. 2014. International Human Rights Law: Cases, Materials, Commentary, 2nd ed. Cambridge: Cambridge University Press.

Shahab, Yasir, Collins G. Ntim, and Farid Ullah. 2018. The Brighter Side of Being Socially Responsible: CSR Ratings and Financial Distress among Chinese State and Non-State Owned Firms. Applied Economics Letters 3: 1-7. [CrossRef]

Shapiro, Daniel, Bersant Hobdari, and Chang Hoon Oh. 2018. Natural Resources, Multinational Enterprises and Sustainable Development. Journal of World Business 53: 1-14. [CrossRef]

Soh, Changrok, and Seunghyun Nam. 2018. Business and Human Rights Case Study of Korean Companies Operating Overseas: Challenges and a New National Action Plan. Human Rights Quarterly 40: 287-316. [CrossRef]

State-Owned Enterprises Must Be 'Role Model' in Respecting Human Rights-UN Report. 2016. Available online: https:/ /news.un.org/en/story/2016/06/532442-state-owned-enterprises-must-be-role-modelrespecting-human-rights-un-report (accessed on 17 June 2016).

States: Sustainable Development Knowledge Platform. n.d. Available online: https:/ / sustainabledevelopment.un. org / memberstates (accessed on 14 October 2018).

Sustainable Development Knowledge Platform. 2018. Available online: https://sustainabledevelopment.un.org/ (accessed on 11 October 2018).

Synthesis of Voluntary National Reviews. 2017. UN DESA. Available online: https:/ / sustainabledevelopment.un. org/.../17109Synthesis_Report_VNRs_2017.pdf (accessed on 12 October 2018).

The World Bank: Raw Materials Group. n.d. “Overview of State Ownership in the Global Minerals Industry-Long Term Trends and Future." Extractive Industries for Development Series \#20 May 2011. Available online: https:/ / openknowledge.worldbank.org/handle/10986/16968 (accessed on 13 February 2019). 
Tignino, Mara. 2018. Private Investments and the Human Right to Water. In Research Handbook on Human Rights and Investments. Edited by Yannick Radi. Cheltenham Glos: Edward Elgar.

UN General Assembly. 2013. Format and Organizational Aspects of the High-Level Political Forum on Sustainable Development. New York: UN General Assembly.

UN General Assembly. 2015a. Transforming Our World: The 2030 Agenda for Sustainable Development. New York: UN General Assembly.

UN General Assembly. 2015b. Addis Ababa Action Agenda of the Third International Conference on Financing for Development (Addis Ababa Action Agenda). New York: UN General Assembly.

UN General Assembly. 2016a. Critical Milestones towards a Coherent, Efficient, and Inclusive Follow-Up and Review of the 2030 Agenda at the Global Level. New York: UN General Assembly.

UN General Assembly. 2016b. Follow-Up and Review of the 2030 Agenda for Sustainable Development at the Global Level. New York: UN General Assembly.

UN Working Group on Business and Human Rights. 2017. The Business and Human Rights Dimension of Sustainable Development: Embedding 'Protect, Respect and Remedy' in SDGs Implementation. Available online: https:/ / www.ohchr.org/.../Business/.../InfoNoteWGBHR_SDGRecommendations.pdf (accessed on 11 October 2018).

UNDP. 2017. Rapid Integrated Assessment: To Facilitate Mainstreaming of SDGs into National and Local Plans. Available online: https://www.undp.org/content/undp/en/home/librarypage/sustainabledevelopment-goals/rapid-integrated-assessment---mainstreaming-sdgs-into-national-a.html (accessed on 3 February 2019).

United Nations, Human Rights Instruments. 2008. Compilation of General Comments and General Recommendations Adopted by Human Rights Treaty Bodies (Volume I). HRI/GEN/1/Rev.9 (Vol. I).

United Nations. 2014. World Investment Report 2014: Investing in the SDGs: An Action Plan. New York and Geneva: United Nations.

United Nations. 2017. World Investment Report 2017: Investment and the Digital Economy. New York and Geneva: United Nations.

United Nations Human Rights Commissioner. 2016. "Protection of the Rights of the Child in the Implementation of the 2030 Agenda for Sustainable Development." A/HRC/34/27. United Nations. Available online: https:/ / doi.org/10.18356/d9bf1c42-en (accessed on 11 October 2018).

Vattenfall. 2016. Power Climate Smarter Living: Vattenfall Annual and Sustainability Report 2016. Available online: https:/ / corporate.vattenfall.com/investors / financial-reports /vattenfalls-year-end-report-2016/ (accessed on 11 January 2018).

Vattenfall. 2017. Vattenfall's Statement on Slavery and Human Trafficking. Available online: https: / / corporate. vattenfall.com/sustainability/policies-and-management/ (accessed on 11 January 2018).

Vinuales, Jorge E. 2008. The Contribution of the International Court of Justice to the Development of International Environmental Law: A Contemporary Assessment. Fordham Int'l LJ 32: 1-38.

Voluntary Common Reporting Guidelines for Voluntary National Reviews at the High-Level Political Forum for Sustainable Development (HLPF). 2018. United Nations, Sustainable Development Knowledge Platform. Available online: https:/ / sustainabledevelopment.un.org/content/documents/17346Updated_Vol-untary_ Guidelines.pdf (accessed on 12 October 2019).

Voluntary National Reviews: Sustainable Development Knowledge Platform. n.d. Available online: https: / / sustainabledevelopment.un.org/vnrs / (accessed on 12 October 2018).

Wenar, Leif. 2015. Blood Oil: Tyrants, Violence, and the Rules That Run the World. Oxford: Oxford University Press. Whelan, Glen, and Judy Muthuri. 2017. Chinese State-Owned Enterprises and Human Rights: The Importance of National and Intra-Organizational Pressures. Business E Society 56: 738-81.

World Commission on Environment and Development. 1987. Our Common Future (Brundtland Report). Oxford: Oxford University Press.

Xu, Danyun, Lei Wang, and Junchang Liu. 2017. Assessing the Social Performance of State-Owned Forest Farms in China: Integrating Forest Social Values and Corporate Social Responsibility Approaches. Scandinavian Journal of Forest Research 32: 338-48. [CrossRef] 
Xue, Lan, Lingfei Weng, and Hanzhi Yu. 2018. Addressing Policy Challenges in Implementing Sustainable Development Goals through an Adaptive Governance Approach: A View from Transitional China. Sustainable Development 26: 150-58. [CrossRef]

Zhu, Jing. 2017. The 2030 Agenda for Sustainable Development and China's Implementation. Chinese Journal of Population Resources and Environment 15: 142-46. [CrossRef] 